\title{
DIGITALCOMMONS
}

@WAYNESTATE-

Journal of Transportation Management

Volume 17 | Issue 2

Article 28

9-1-2006

\section{Evaluating the Comparative Efficiency of Eleven States' Highway Expenditures}

Hokey Min

Bowling Green State University

Thomas Lambert

Indiana University Southwest

Follow this and additional works at: https://digitalcommons.wayne.edu/jotm

Part of the Operations and Supply Chain Management Commons, and the Transportation Commons

\section{Recommended Citation}

Min, Hokey \& Lambert, Thomas. (2006). Evaluating the Comparative Efficiency of Eleven States' Highway Expenditures. Journal of Transportation Management, 17(2), 46-62. doi: 10.22237/jotm/1157069220

This Article is brought to you for free and open access by the Open Access Journals at DigitalCommons@WayneState. It has been accepted for inclusion in Journal of Transportation Management by an authorized editor of DigitalCommons@WayneState. 


\section{Evaluating the Comparative Efficiency of Eleven States' Highway Expenditures}

\section{Cover Page Footnote}

The authors would like to thank Usher Transport Inc. for partly funding this research. 


\title{
Evaluating the Comparative Efficiency of Eleven States' Highway Expenditures
}

\author{
Hokey Min \\ Bowling Green State University \\ Thomas Lambert \\ Indiana University Southeast
}

\begin{abstract}
In an era of budget deficits and financial cutbacks, the efficiency of state highway finances dictates future investment in road construction and maintenance. Considering the significant impact of highway infrastructure on the survival and competitiveness of the logistics industry, this paper aims to develop a meaningful set of benchmarks that will guide the state government authority in making wise investment decisions regarding road construction and maintenance. In particular, we propose a data envelopment analysis that is proven to be useful for measuring the operational efficiency of various profit or non-profit organizations. Using the examples of state highway finances for Kentucky and other comparable states in the United States, this paper illustrates the usefulness of data envelopment analysis for the efficient allocation of financial resources to road construction and maintenance.
\end{abstract}

\section{INTRODUCTION}

As a growing number of state governments in the United States have begun to experience severe budget shortfalls, they often resort to tax increases to balance their budgets. However, during the economic doldrums, tax increases can backfire, because they put more financial burden on businesses that have already suffered from slow revenue growth. Such businesses include the trucking industry that has historically operated on profit margins as low as $3 \%$ of sales after taxes, compared to the 7 to $9 \%$ average profit margin experienced by the heavy manufacturing industry (Dun and Bradstreet, 1999; Lambert and Min, 2000; American Trucking Associations Economics and Statistics
Group, 2004). Recently, the profit margin of the trucking industry shrank further; for instance, the profit margin declined from 3.08\% in 1994 to $2.60 \%$ in 1999 (American Trucking Associations Economics and Statistic Group, 2001). With tight profit margins and increasing competition, additional tax hikes for the trucking industry can drive some struggling trucking firms out of business and consequently dwindle future tax bases. Despite such concerns, commercial carriers paid $\$ 30.2$ billion in federal highwayuser taxes in 2002, approximately $40 \%$ of all highway user fees (American Trucking Associations Economics and Statistics Group, 2004). In addition, to fund impending $\$ 375$ billion highway construction and maintenance projects, the trucking industry may need to 
absorb a 5-cents-a gallon hike in the gasoline tax (USA Today, 2004). For instance, U.S. diesel fuel prices have risen from approximately $\$ 2.00$-agallon to $\$ 3.00$-a-gallon from summer of 2004 to summer of 2006 (Energy Information Agency, 2006).

Faced with potential tax hikes coupled with rising gasoline prices and costly road projects, some tax payers including the trucking industry scrutinized how tax revenues had been utilized by state governments. For example, it was recently reported that Jefferson County (the main county of the Louisville Metropolitan Area) in Kentucky received less than $\$ 100$ million annually after it generated approximately $\$ 200$ million state and federal transportation revenues (Timmons, 2003). That is to say, Jefferson County lost more than $\$ 1$ billion of road funds for the past decade due to huge differentials between what tax payers paid for state services and what they actually received. To make matters worse, the lack of road funds may halt or delay indefinitely state road constriction projects (e.g., Kentucky 22 at the interchange with the Gene Snyder Freeway in Jefferson County) and can create prolonged traffic congestion (Associated Press, 2003). Since prolonged traffic congestion negatively affects a truck's on-time delivery services and fuel costs, underutilized transportation tax revenue can hurt the long term competitiveness of trucking firms and the political stability of a state government.

Considering the significant impact of state taxes on the viability of the trucking industry, it may be worth examining the comparative efficiency of state highway finances and then setting a reliable performance standard for state governments. Examples of such a standard are a financial audit, an industry norm, and a benchmark. Since a state government needs to measure its financial performance relative to its peer states to constantly avoid budget shortfalls and then gain a position of "the best of breeds," benchmarking seems to be the most effective way of setting a reliable financial standard and then measuring the operational efficiency of the state government.

In general, benchmarking is a continuous quality improvement process by which an organization can assess its internal strengths and weaknesses, evaluate comparative advantages of leading competitors, identify the best practices of industry functional leaders, and incorporate these findings into a strategic action plan geared to gain a position of superiority (Min and Galle, 1996). The main goals of benchmarking are to

Identify key performance measures for each function of a business operation; Measure one's own internal performance levels as well as those of the leading competitors; Compare performance levels and identify areas of comparative advantages and disadvantages; Implement programs to close a performance gap between internal operations and the leading competitors (Furey 1987, p.30).

In setting the benchmark, this paper will measure the efficiency of state governments' road finances relative to prior periods and their peers. The relative efficiency measured by input/output ratios can reflect the true overall productivity of state governments better than traditional financial ratios, such as, return on investments and assets that tend to focus on myopic aspects of financial performances. As a way of comparatively assessing the productivity of state governments with multiple inputs and outputs, this paper proposes a data envelopment analysis (DEA) which was successfully explored in measuring the operational efficiency of banks (e.g., Thanassoulis, 1999), hospitals (Valdmanis, 1992), nursing homes (Kleinsorge and Karney, 1992), intergovernmental revenue transfers (Ali et al., 1993), purchasing departments (Murphy et al., 1996), cellular manufacturing (Talluri et al., 1997), travel demand (Nozick et al., 1998), information technology investments (Shafer and Byrd, 2000), customer service performances of less-than-truckload (LTI,) motor carriers (Poli and Scheraga, 2000), international ports 
(Tongzon, 2001) and trucking firms (Min and Joo, 2003). For further details on other DEA applications, interested readers should refer to Seiford (1990). In general, DEA is referred to as a linear programming (non-parametric) technique that converts multiple incommensurable inputs and outputs of each decision-making unit (DMU) into a scalar measure of operational efficiency, relative to its competing DMU's. Herein, DMU's refer to the collection of private firms, non-profit organizations, departments, administrative units, and groups with the same (or similar) goals, functions, standards and market segments. DEA is designed to identify the best practice DMU without a priori knowledge of which inputs and outputs are most important in determining an efficiency measure (i.e., score) and assess the extent of inefficiency for all other DMU's that are not regarded as the best practice DMU's (e.g., Charnes et al., 1978). Since DEA provides a relative measure, it will only differentiate the least efficient DMU from the set of all DMU's. Thus, the best practice (most efficient) DMU is rated as an efficiency score of one, whereas all other less efficient DMU's are scored somewhere between zero and one. To summarize, DEA determines the following (Sherman and Ladino, 1995):

- The best practice DMU that uses the least resources to provide its products or services at or above the quality standard of other DMU's;

- The less efficient DMU's compared to the best practice DMU;

- The amount of excess resources used by each of the less efficient DMU's;

- The amount of excess capacity or ability to increase outputs for less efficient DMU's without requiring added resources.

In measuring the comparative efficiency of state highway finances, we chose DEA over other alternative techniques, such as Cobb Douglas functions and analytic hierarchy process (AHP), because DEA reflects the multiple aspects of organizational performances, does not require $a$ priori weights of performance measures, and provides valuable insights as to how operational efficiency can be improved.

\section{SPECIFICATION OF INPUT AND OUTPUT MEASURES}

The assessment of comparative efficiency using DEA begins with the selection of appropriate input and output measures that can be aggregated into a composite index of overall performance standards. Although any resources used by DMU should be included as input, five different metrics were selected as inputs (see Table 1). These are composite index for highway construction costs, total capital outlays, total maintenance costs, motor fuel taxes, and motor vehicle taxes.

Since both federal and state highway revenues are often distributed for the construction and improvement of urban and rural highway systems, highway construction costs can be a key expenditure for road funds and state budgets. Thus, a composite index for highway construction costs is considered a proxy for measuring an efficiency of state budget management and should be chosen as one of the inputs. The composite index includes costs associated with materials (e.g., cement, bituminous surfaces, gravel, sand, slag, steel, concrete pipe, clay pipe, lumber, petroleum), supplies, equipment (including mobilization, fuel and lubricants, licenses, insurances) and with labor needed for highway construction.

Capital outlays are those costs associated with highway improvements, including land acquisition and other right-of-way costs; preliminary construction engineering; reconstruction; resurfacing, rehabilitation and restoration of roadways and structures; and installation of traffic service facilities such as guard rails, fencing, signs, and signals (Larson, 1991). Thus, capital outlays are viewed as expenditures (inputs), because the utilization of capital outlays can increase the efficiency of highway operation and maintenance. 


\section{TABLE 1}

DESCRIPTIVE STATISTICS FOR INPUT AND OUTPUT MEASURES

\begin{tabular}{|c|c|c|c|c|c|c|}
\hline & $\begin{array}{c}\text { Number } \\
\text { of } \\
\text { annual } \\
\text { reports }\end{array}$ & Minimum & Maximum & Mean & $\begin{array}{l}\text { Standard } \\
\text { Deviation }\end{array}$ & Type \\
\hline Total receipts & 33 & $442,119^{*}$ & $3,860,474^{*}$ & $1,865,127^{*}$ & $1,025,388^{*}$ & Output \\
\hline $\begin{array}{l}\text { Composite index } \\
\text { for highway } \\
\text { construction costs }\end{array}$ & 33 & 107.27 & 353.67 & 157.34 & 44.41 & Input \\
\hline $\begin{array}{l}\text { Total capital } \\
\text { outlays }\end{array}$ & 33 & $235,891^{*}$ & $2,167,981^{*}$ & $984,146^{*}$ & $514,655^{*}$ & Input \\
\hline $\begin{array}{l}\text { Total } \\
\text { maintenance } \\
\text { costs }\end{array}$ & 33 & $52,181^{*}$ & $838,539^{*}$ & $304,549^{*}$ & $185,524^{*}$ & Input \\
\hline Motor fuel taxes & 33 & $158,957^{*}$ & $1,425,771^{*}$ & $650,545^{*}$ & $361,083^{*}$ & Input \\
\hline $\begin{array}{l}\text { Motor vehicle and } \\
\text { carrier taxes }\end{array}$ & 33 & $34,670^{*}$ & $1,020,947^{*}$ & $372,564^{*}$ & $274,874^{*}$ & Input \\
\hline
\end{tabular}

* These figures are measured in thousands of dollars.

Also, maintenance costs are considered to be expenditures given that they can prolong the life of highways by preventing early road wear. In general, maintenance costs are those required to keep the highways in usable conditions, such as routine patching repairs, bridge painting, and other maintenance costs; and traffic service costs, such as snow and ice removal, pavement markings, signs, litter cleaning, and toll collection expenses (Larson, 1991).

Since taxes such as motor fuel taxes and motor vehicle taxes are the chief sources of locally generated funds utilized by state governments to finance highway programs, we regarded both motor fuel (e.g., gasoline) taxes and motor vehicle and carrier taxes as key inputs. These taxes are levied on owners and operators of motor vehicles because of their use of public highways and are levied uniformly throughout the state. In particular, motor fuel taxes account for more than $60 \%$ of all road user taxes and have become a dominant component of highway funds (Small et al., 1989). However, motor fuel taxes often evoke considerable public debate due to their instability resulting from constant fluctuations of oil prices and due to heavy opposition from the trucking industry to tax hikes. Thus, it is worth investigating whether such taxes are set fairly and efficiently. For a similar reason, the use of motor vehicle and carrier taxes by state governments will be scrutinized.

On the output side, the overall performance of state highway finances can be measured by highway receipts that best reflect the efficiency of state governments in managing highway funds and allocated budgets. Highway receipts represent highway user revenues and all other receipts applied for highway purposes regardless of sources (Larson, 1991). Highway receipts include federal highway trust funds, appropriated general funds, grants-in-aids, registration fees, license fees, toll receipts, parking revenues, interest income, rentals, donations, royalties, 
bond proceeds, and profits from the purchase and sale of securities. The input and output data were obtained from a series of highway statistics that were summarized and reported by the Federal Highway Administration (Larson, 1991; Office Highway Policy Information, 2002). This paper analyzed three years of data for 11 state governments made up of Arkansas, Idaho, Indiana, Illinois, Kentucky, Missouri, Ohio, South Carolina, Tennessee, Virginia, and West Virginia.

To maintain comparability and homogeneity among the states, we excluded 40 states that have different geographical, economic, and transportation characteristics than these selected states from the current DEA analysis. A hierarchical cluster analysis using Statistical Package for the Social Sciences for Windows (2004) was used to confirm our choice of peer states listed above. An appropriate grouping of states is critical to the analysis. The Office of Highway Policy Information (2002) noted that the estimation of state maintenance expenditures provided a clear example of difficulty in comparing states. Maintenance expenditures per mile can vary among states depending upon climate, geographic locations, composition of capital expenditures, traffic congestion, the extent of truck traffic, degree of urbanization, pavement roughness, and the level of system responsibility retained by the state versus other levels of government. With this in mind, these variations were controlled in the selection of peer states by using cluster analysis to group states according to their similarities (or Euclidean dissimilarity coefficient matrix) on characteristics such as ratio of urban to rural roadway miles, weather, millions of vehicle miles traveled per year, per capita income, gross state product per capita, and population per square mile.

\section{DATA ENVELOPMENT ANALYSIS MODEL DESIGN AND TESTING}

The DEA model, with the inputs and output. summarized in Table 1, was adopted for this study. The DEA model is mathematically expressed as

$$
\begin{aligned}
& \text { Maximize efficiency score }(j p)=\frac{\sum_{r=1}^{t} u_{r} v_{r, p}}{\sum_{i=1}^{m} r_{i}, x_{r p}} \\
& \text { Subject to } \frac{\sum_{r=1}^{t} u_{r} v_{n}}{\sum_{i=1}^{m} v_{i} x_{t}} \leq 1, \quad \mathrm{j}=1, \ldots, n, \\
& u_{r}, u_{i} \geq \varepsilon, \forall r \text { and } i \text {, }
\end{aligned}
$$

where

$y_{r}=$ amount of output $r$ produced by $\mathrm{DMU} j$,

$x_{i}=$ amount of input $i$ used by IMU $j$,

$u_{r}=$ the weight given to output $r$,

$v_{i}=$ the weight given to input $i$,

$n=$ the number of DMU's,

$t=$ the number of outputs,

$m=$ the number of inputs,

$\varepsilon=$ a small positive number.

To ease computational complexity associated with the fractional nonlinear form of Equations (1), (2), and (3) (above) can be converted into a linear program as follows.

Maximize efficiency score $(j p)=\sum_{r=1}^{p} u_{r}, v_{r i p}$ 


$$
\begin{aligned}
& \text { Subject to } \sum_{i=1}^{m} v_{i} x_{u p}=a, \\
& \sum_{r=1}^{i} u_{r} y_{r}-\sum_{i=1}^{m} v_{i} x_{u} \leq 0, j=1, \ldots, n, \\
& -u_{r} \leq-\varepsilon, \quad r=1, \ldots, t, \\
& -v_{i} \leq-\varepsilon, \quad i=1, \ldots, m,
\end{aligned}
$$

where $a=$ an arbitrarily set constant (e.g., 100). By solving the above equations (4)-(8), the efficiency of IMMU $(j p)$ is maximized subject to the efficiencies of all DMU's in the set with an upper bound of 1 . The above model is solved $n$ times to evaluate the relative efficiency of each I)MU. Notice that the weights $u_{r}$ and $v_{\imath}$ are treated as unknown variables whose values will be optimally determined by maximizing the efficiency of the targeted DMU jp. An efficiency score $(j p)$ of 1 indicates that the DMU under consideration is efficient relative to other DMU's, while an efficiency score of less than 1 indicates the IMMU under consideration is inefficient. In a broader sense, an efficiency score represents a state government's ability to transform a set of inputs (given resources) into a set of outputs.
The above model also identifies a peer group (efficient DMU with the same weights) for the inefficient DMU (Boussofiane et al., 1991).

A complete DEA analysis was conducted by applying a non-linear fractional program formulated in equations (1)-(3) to actual data containing a sample of 11 states with three consecutive years of performance measures. The results obtained from the use of Frontier Analyst software (1998) show that Virginia consistently recorded an efficiency score of $1(100 \%)$ in 1999 through 2001. Ohio achieved an efficiency score of $1(100 \%)$ in 1999 and bounced back in 2001 after losing its efficiency in 2000. Arkansas, Indiana, Illinois and South Carolina registered an efficiency score of $1(100 \%)$ once during the three year span (see Table 2). On a year-to-year basis, at least two states are considered efficient every year. However, the average efficiency score of 11 states gradually dipped over the three year span and caused increased concern over their highway finances. In particular, Idaho, Kentucky and Tennessee never rated as efficient and consistently scored below average for the last three years (1999,2000, and 2001) with respect to efficiency scores for total receipts (Table 2).

TABLE 2

EFFICIENCY SCORES FOR TOTAL RECEIPTS

\begin{tabular}{lrrrr}
\hline \multirow{2}{*}{ State } & \multicolumn{3}{c}{ Year } \\
\cline { 2 - 5 } & $\mathbf{1 9 9 9}$ & $\mathbf{2 0 0 0}$ & $\mathbf{2 0 0 1}$ & Average \\
\hline Arkansas & $85.66 \%$ & $100.00 \%$ & $69.10 \%$ & $84.92 \%$ \\
Idaho & $89.45 \%$ & $86.21 \%$ & $87.64 \%$ & $87.77 \%$ \\
Indiana & $96.58 \%$ & $94.22 \%$ & $100.00 \%$ & $96.93 \%$ \\
Illinois & $97.47 \%$ & $100.00 \%$ & $98.15 \%$ & $98.54 \%$ \\
Kentucky & $78.19 \%$ & $88.44 \%$ & $79.67 \%$ & $82.10 \%$ \\
Missouri & $83.48 \%$ & $98.89 \%$ & $76.02 \%$ & $86.13 \%$ \\
Ohio & $100.00 \%$ & $89.02 \%$ & $100.00 \%$ & $96.34 \%$ \\
South Carolina & $100.00 \%$ & $82.47 \%$ & $97.62 \%$ & $93.36 \%$ \\
Tennessee & $91.35 \%$ & $83.14 \%$ & $84.37 \%$ & $86.29 \%$ \\
Virginia & $100.00 \%$ & $100.00 \%$ & $100.00 \%$ & $100.00 \%$ \\
West Virginia & $96.67 \%$ & $77.48 \%$ & $80.69 \%$ & $84.95 \%$ \\
\hline \multicolumn{1}{c}{ Average } & $92.62 \%$ & $91.44 \%$ & $88.48 \%$ & $90.85 \%$ \\
\hline
\end{tabular}


For example, Arkansas recorded an efficiency score of only $69.10 \%$ in 2001 leaving ample room for improvement. In 2001 it could have improved its efficiency in total receipts by nearly twice as much (see Table 3). Similarly, Kentucky was the worst performer in 1999, and then improved slightly in 2000 . However, it still registered one of the lowest efficiency scores (third lowest among the eleven states) in 2001. Overall, Kentucky turned out to be the worst performer among 11 states in terms of its average efficiency score for the three year span.

The input utilization rates summarized in Table 4 show that Kentucky's composite index for highway construction costs are unusually high in comparison to other peer states. Idaho is the only other state that underutilized its construction funds worse than Kentucky (see Table 4). As indicated earlier, Kentucky's struggle with construction cost control may stem from its sole sourcing practice of using a particular contractor and the subsequent high price tag associated with highway construction. On the other hand, Kentucky fully utilized its capital outlays, maintenance funds, and income generated from motor fuel taxes. Another concern is that Kentucky poorly utilized income generated from motor vehicle and carrier taxes. With the exception of 1999, Kentucky ranked lowest in terms of utilizing its income generated by motor vehicle and carrier taxes. This result implied that Kentucky might have levied the higher motor vehicle and carrier taxes on trucking firms than it should, or the income generated by motor vehicle and carrier taxes was not efficiently used. It is also ironic to find that Kentucky received in federal funds more than its residents paid in federal taxes in 2002 (Table 5). That is to say, federal funds received by Kentucky may have not been used efficiently. The further examination of several key tax revenues for Kentucky reveals the following:

1. Motor fuel taxes. The tax on gasoline is $\mathbf{1 6 . 4}$ cents per gallon (of which 1.4 cents goes to insure oil companies for leaking underground storage tanks), and the tax on diesel fuel is 18.4 cents per gallon. Kentucky has not had a gasoline tax increase since 1986, and $40 \%$ of the $\$ 1.1$ billion Kentucky Road Fund comes from motor fuel receipts (Loftus, 2003).

2. Motor vehicle usage tax. Kentucky levies a $6 \%$ sales tax on the purchase of a new vehicle in the state, and a usage tax on all vehicles according to their assessed value. This tax accounts for roughly another $40 \%$ of Road Fund revenues (Loftus, 2003).

3. Debt and bond proceeds. This totaled $\$ 29.1$ million for fiscal year 2003. Currently, debt and bond proceeds account for $15 \%$ of Road Fund revenue, far exceeding the recommended level of $6 \%$ (Kentuckians for Better Transportation, 2003).

The adequacy of the aforementioned revenues has been a subject of debate after the Kentucky state government proposed raising gasoline taxes in 2000 to fund new road construction as part of Kentucky's Six-Year Road Plan for 2002-2008. Although the state legislature rejected tax increase, it approved dozens of new road construction projects. To pay for new projects, the legislature allowed the state government to use cash reserves in the state's Road Fund, which at that time exceeded $\$ 700$ million. However, those reserves are expected to vanish by the end of 2003, which would force the postponement and delay of many road projects, some of which are already under way. Such delays will eventually drive up construction costs. This vicious cycle of revenue shortfalls have caused highway construction costs to be higher than other peer states (Table 6 ). To cope with excessive construction costs, the Kentucky legislature mandated that all projects which were $15 \%$ over budget be approved by a legislative review committee. Regardless, there were 562 project cost overruns in excess of $15 \%$ of estimated costs from 1992 to 1998 . These cost overruns totaled $\$ 265$ million, yet funding for all cost overruns were approved (Stevens, 1998).

Another reason for higher construction costs is an apparent lack of competition among highway road contactors in Kentucky. Loftus (2001) 
TABLE 3

POTENTLAL IMPROVEMENTS IN TOTAL RECEIPTS

\begin{tabular}{lrrr}
\hline State & \multicolumn{3}{c}{ Year } \\
\cline { 2 - 4 } Arkansas & $\mathbf{1 9 9 9}$ & $\mathbf{2 0 0 0}$ & $\mathbf{2 0 0 1}$ \\
\cline { 2 - 4 } Idaho & $16.74 \%$ & $0 \%$ & $44.71 \%$ \\
Indiana & $11.79 \%$ & $15.99 \%$ & $\mathbf{1 4 . 1 1 \%}$ \\
Illinois & $3.54 \%$ & $6.13 \%$ & $0 \%$ \\
Kentucky & $2.60 \%$ & $0 \%$ & $1.88 \%$ \\
Missouri & $27.89 \%$ & $13.07 \%$ & $25.52 \%$ \\
Ohio & $19.79 \%$ & $1.12 \%$ & $31.54 \%$ \\
South Carolina & $0 \%$ & $12.34 \%$ & $0 \%$ \\
Tennessee & $0 \%$ & $21.25 \%$ & $2.44 \%$ \\
Virginia & $9.47 \%$ & $20.28 \%$ & $18.53 \%$ \\
West Virginia & $0 \%$ & $0 \%$ & $0 \%$ \\
\hline
\end{tabular}

TABLE 4

RESOURCE (INPUT) UTIIIZATION RATES IN PERCENTAGE

\begin{tabular}{|c|c|c|c|c|}
\hline & \multirow{2}{*}{ State } & \multicolumn{3}{|c|}{ Year } \\
\hline & & 1999 & 2000 & 2001 \\
\hline \multirow{3}{*}{ Resources } & Arkansas & $-18.07 \%$ & $0 \%$ & $-33.71 \%$ \\
\hline & Idaho & $.86 .22 \%$ & $-78.47 \%$ & $-86.14 \%$ \\
\hline & Indiana & $-29.52 \%$ & $0 \%$ & $0 \%$ \\
\hline \multirow{8}{*}{$\begin{array}{l}\text { Composite } \\
\text { Index of } \\
\text { Highway } \\
\text { Construc- } \\
\text { tion Costs }\end{array}$} & Illinois & $0 \%$ & $0 \%$ & $0 \%$ \\
\hline & Kentucky & $-31.11 \%$ & $-39.17 \%$ & $-23.96 \%$ \\
\hline & Missouri & $0 \%$ & $0 \%$ & $-14.78 \%$ \\
\hline & Ohio & $0 \%$ & $0 \%$ & $0 \%$ \\
\hline & South Carolina & $0 \%$ & $-3.17 \%$ & $0 \%$ \\
\hline & Tennessee & $0 \%$ & $0 \%$ & $0 \%$ \\
\hline & Virginia & $0 \%$ & $0 \%$ & $0 \%$ \\
\hline & West Virginia & $-31.81 \%$ & $0 \%$ & $0 \%$ \\
\hline \multirow{11}{*}{$\begin{array}{l}\text { Total } \\
\text { Capital } \\
\text { Outlays }\end{array}$} & Arkansas & $0 \%$ & $0 \%$ & $0 \%$ \\
\hline & Idaho & $0 \%$ & $0 \%$ & $0 \%$ \\
\hline & Indiana & $0 \%$ & $0 \%$ & $0 \%$ \\
\hline & Illinois & $0 \%$ & $0 \%$ & $-4.83 \%$ \\
\hline & Kentucky & $0 \%$ & $0 \%$ & $0 \%$ \\
\hline & Missouri & $0 \%$ & $0 \%$ & $0 \%$ \\
\hline & Ohio & $0 \%$ & $0 \%$ & $0 \%$ \\
\hline & South Carolina & $0 \%$ & $0 \%$ & $0 \%$ \\
\hline & Tennessee & $0 \%$ & $0 \%$ & $0 \%$ \\
\hline & Virginia & $0 \%$ & $0 \%$ & $0 \%$ \\
\hline & West Virginia & $0 \%$ & $0 \%$ & $-0.15 \%$ \\
\hline
\end{tabular}


Table 4

(continued)

\begin{tabular}{|c|c|c|c|c|}
\hline & \multirow{2}{*}{ State } & \multicolumn{3}{|c|}{ Year } \\
\hline & & 1999 & 2000 & 2001 \\
\hline \multirow{4}{*}{ Resources } & Arkansas & $-11.79 \%$ & $0 \%$ & $0 \%$ \\
\hline & Idaho & $0 \%$ & $-10.09 \%$ & $0 \%$ \\
\hline & Indiana & $-12.51 \%$ & $-4.69 \%$ & $0 \%$ \\
\hline & Illinois & $0 \%$ & $0 \%$ & $0 \%$ \\
\hline \multirow{7}{*}{$\begin{array}{l}\text { Total Main- } \\
\text { tenance } \\
\text { Costs }\end{array}$} & Kentucky & $0 \%$ & $0 \%$ & $0 \%$ \\
\hline & Missouri & $-32.40 \%$ & $-31.88 \%$ & $0 \%$ \\
\hline & Ohio & $0 \%$ & $0 \%$ & $0 \%$ \\
\hline & South Carolina & $0 \%$ & $-33.51 \%$ & $-6.03 \%$ \\
\hline & Tennessee & $-21.63 \%$ & $-12.96 \%$ & $-23.99 \%$ \\
\hline & Virginia & $0 \%$ & $0 \%$ & $0 \%$ \\
\hline & West Virginia & $-53.62 \%$ & $-18.20 \%$ & $-0.69 \%$ \\
\hline \multirow{11}{*}{$\begin{array}{l}\text { Motor Fuel } \\
\text { Taxes }\end{array}$} & Arkansas & $-2.45 \%$ & $0 \%$ & $-28.96 \%$ \\
\hline & Idaho & $0 \%$ & $0 \%$ & $0 \%$ \\
\hline & Indiana & $-3.05 \%$ & $-21.77 \%$ & $0 \%$ \\
\hline & Illinois & $0 \%$ & $0 \%$ & $0 \%$ \\
\hline & Kentucky & $0 \%$ & $0 \%$ & $0 \%$ \\
\hline & Missouri & $-12.32 \%$ & $-10.38 \%$ & $-9.14 \%$ \\
\hline & Ohio & $0 \%$ & $-0.86 \%$ & $0 \%$ \\
\hline & South Carolina & $0 \%$ & $-38.66 \%$ & $-75.20 \%$ \\
\hline & Tennessee & $-21.87 \%$ & $-31.10 \%$ & $-13.31 \%$ \\
\hline & Virginia & $0 \%$ & $0 \%$ & $0 \%$ \\
\hline & West Virginia & $0 \%$ & $0 \%$ & $0 \%$ \\
\hline \multirow{11}{*}{$\begin{array}{l}\text { Motor } \\
\text { Vehicle and } \\
\text { Carrier } \\
\text { Taxes }\end{array}$} & Arkansas & $0 \%$ & $0 \%$ & $0 \%$ \\
\hline & Idaho & $-2.02 \%$ & $-33.11 \%$ & $0 \%$ \\
\hline & Indiana & $0 \%$ & $0 \%$ & $0 \%$ \\
\hline & Illinois & $-13.90 \%$ & $0 \%$ & $-17.16 \%$ \\
\hline & Kentucky & $-43.74 \%$ & $-59.66 \%$ & $-48.04 \%$ \\
\hline & Missouri & $0 \%$ & $0 \%$ & $0 \%$ \\
\hline & Ohio & $0 \%$ & $0 \%$ & $0 \%$ \\
\hline & South Carolina & $0 \%$ & $0 \%$ & $0 \%$ \\
\hline & Tennessee & $0 \%$ & $0 \%$ & $0 \%$ \\
\hline & Virginia & $0 \%$ & $0 \%$ & $0 \%$ \\
\hline & West Virginia & $-84.92 \%$ & $-22.09 \%$ & $0 \%$ \\
\hline
\end{tabular}

* Negative values show underutilization of resources and zero values indicate full utilization. 
TABLE 5

GOVERNMENT SPENDING PER TAX DOLLAR

\begin{tabular}{lcccc}
\hline State & 2002 Spending & 2002 Rank & 1992 Spending & 1992 Rank \\
\hline Arkansas & $\$ 1.55$ & 2 & $\$ 1.28$ & 4 \\
Idaho & $\$ 1.31$ & 6 & $\$ 1.25$ & 5 \\
Indiana & $\$ 1.00$ & 10 & $\$ 0.83$ & 10 \\
Illinois & $\$ 0.77$ & 11 & $\$ 0.72$ & 11 \\
Kentucky & $\$ 1.50$ & 3 & $\$ 1.20$ & 7 \\
Missouri & $\$ 1.34$ & 4 & $\$ 1.25$ & 5 \\
Ohio & $\$ 1.03$ & 9 & $\$ 0.94$ & 9 \\
South Carolina & $\$ 1.34$ & 4 & $\$ 1.29$ & 3 \\
Tennessee & $\$ 1.26$ & 7 & $\$ 1.11$ & 8 \\
Virginia & $\$ 1.13$ & 8 & $\$ 1.39$ & 2 \\
West Virginia & $\$ 1.82$ & 1 & $\$ 1.44$ & 1 \\
\hline
\end{tabular}

Source: The Tax Foundation and USA Today (2003)

Note: This table shows how much the federal government spends in each state for every dollar state residents pay in federal taxes. The higher the ranking, the more a state receives in funds than it pays in taxes.

TABLE 6

COST INDICES AND AVERAGES FOR

FEDERAI,-AID HIGHWAY CONSTRUCTION, 1992-2001

\begin{tabular}{lrrrrrrrrrrr}
\hline & $\mathbf{2 0 0 1}$ & $\mathbf{2 0 0 0}$ & $\mathbf{1 9 9 9}$ & $\mathbf{1 9 9 8}$ & $\mathbf{1 9 9 7}$ & $\mathbf{1 9 9 6}$ & $\mathbf{1 9 9 5}$ & $\mathbf{1 9 9 4}$ & $\mathbf{1 9 9 3}$ & $\mathbf{1 9 9 2}$ & Average \\
\hline Arkansas & 152.7 & 148.0 & 135.6 & 116.6 & 123.3 & 109.7 & 103.8 & 107.4 & 96.8 & 99.8 & 119.4 \\
Illinois & 143.6 & 132.0 & 131.6 & 135.2 & 123.4 & 112.2 & 123.1 & 115.4 & 107.3 & 105.1 & 122.9 \\
Indiana & 176.1 & 158.4 & 150.9 & 149.7 & 145.4 & 153.1 & 141.9 & 135.9 & 116.1 & 109.8 & 143.7 \\
Kentucky & 194.9 & 195.7 & 199.7 & 197.0 & 156.9 & 149.8 & 175.0 & 103.4 & 143.8 & 96.4 & 161.2 \\
Missouri & 353.7 & 165.9 & 163.9 & 96.1 & 143.3 & 108.0 & 129.9 & 119.6 & 109.8 & 108.4 & 149.8 \\
Ohio & 110.9 & 139.6 & 117.0 & 110.5 & 112.5 & 115.1 & 97.8 & 102.2 & 86.3 & 147.6 & 113.9 \\
S. Carolina & 213.7 & 172.4 & 178.9 & 172.8 & 137.8 & 124.5 & 132.7 & 135.5 & 100.2 & 95.9 & 146.4 \\
Tennessee & 134.7 & 191.0 & 133.0 & 159.5 & 136.0 & 129.0 & 125.9 & 115.4 & 109.8 & 118.7 & 135.3 \\
Virginia & 162.6 & 110.6 & 120.9 & 122.8 & 130.8 & 114.8 & 118.8 & 121.2 & 99.5 & 97.1 & 119.9 \\
W. Virginia & 107.3 & $\mathbf{1 3 6 . 4}$ & 147.1 & 119.1 & 125.3 & 147.9 & 102.5 & 121.5 & 84.9 & 77.7 & 117.0 \\
\hline
\end{tabular}

Source: Federal Highway Administration

Notes: 1987 is the base year $(1987=100)$. Indices are based on information submitted for Federal aid construction contracts over $\$ 500,000$. The base for each state index is its own particular "market basket" of quantities and costs during the base period. The composite index for each state measure the change in that state's index since base year 1987. (In 1987 each state's index equaled 100). 
reported that bidding for state government resurfacing contracts has been marked by a lack of competition in vast regions of Kentucky for decades. For example, from 1988 to 1994, the Kentucky Transportation Cabinet received only one bid for approximately more than half (58\%) of the road resurfacing contracts that it awarded. Also, some contractors appeared to have virtual monopolies in certain regions of the state where most, if not all, major projects were done in contiguous counties by the same contractor year after year (Loftus, 2001). With little or no competition, prices for resurfacing contracts are set higher than would be the case in a more competitive market. In such a monopoly situation, the contractor is also likely to build highways of sub-standard quality and subsequently increase maintenance costs.

To summarize, southern states such as Kentucky and Tennessee struggled throughout the sample period, whereas mid-western states such as Ohio, Illinois and Indiana fared better. Both Kentucky and Tennessee significantly underutilized their funds generated by taxes (either motor vehicle tax or motor fuel tax), whereas good performing states such as Ohio, Illinois and Indiana better utilized their tax generated funds. Interestingly, it was discovered that poor performing states such as Kentucky and Tennessee tend to suffer from higher trucking business failure rates than good performing states such as Ohio, Illinois, Indiana and Virginia as shown in Table 7.
In addition, the sensitivity of the results and findings to changes in the specification of DEA input measures was investigated. For instance, the impact of introducing highway administration, research, and planning budget and income generated by law enforcement and safety into the DEA analysis was examined. This model experiment still suggests that the basic findings are relatively robust and do not change significantly when certain input measures are replaced with new input parameters. The only exception may be South Carolina whose efficiency dropped due to the poor utilization of income generated by law enforcement and safety (Tables 8 and 9).

\section{CONCLUSIONS AND MANAGERIAL IMPIJCATIONS}

In general, good roads not only contribute to quality of life, but also help cities and states develop economically (Chandra and Thompson, 2000). (On the other hand, poor road conditions cause $35 \%$ of the 43,000 vehicle fatalities in the United States each year, and traffic congestion resulting from poor road conditions costs the United States $\$ 70$ billion in wasted fuel and productivity (USA Today, 2004). Also, a lack of good roads can increase costs of road construction and maintenance. For example, excessive road construction costs can cause not only the delay of other necessary projects that wait for funding, but also burden state residents

TABLE 7

AVERAGE TRUCKING BUSINESS FAILURE RATES (1984-1995)

\begin{tabular}{lc}
\hline State & Failure Rate per 10,000 Firms \\
\hline Tennessee & 456 \\
Kentucky & 434 \\
Indiana & 423 \\
Illinois & 352 \\
Ohio & 345 \\
Virginia & 340 \\
\hline
\end{tabular}

Source: Dun and Bradstreet, Inc. (1999) 
TABLE 8

EFFICIENCY SCORES FOR TOTAL RECEIPTS (ALTERNATIVE MODEL)

\begin{tabular}{lrrr}
\hline State & \multicolumn{3}{c}{ Year } \\
\cline { 2 - 4 } & $\mathbf{1 9 9 9}$ & $\mathbf{2 0 0 0}$ & $\mathbf{2 0 0 1}$ \\
\hline Arkansas & $86.00 \%$ & $100 \%$ & $74.17 \%$ \\
Idaho & $96.25 \%$ & $86.88 \%$ & $85.51 \%$ \\
Indiana & $100 \%$ & $94.60 \%$ & $100 \%$ \\
Illinois & $99.27 \%$ & $100 \%$ & $92.07 \%$ \\
Kentucky & $80.97 \%$ & $88.49 \%$ & $84.61 \%$ \\
Missouri & $89.03 \%$ & $99.22 \%$ & $74.63 \%$ \\
Ohio & $100 \%$ & $96.40 \%$ & $100 \%$ \\
South Carolina & $85.06 \%$ & $74.69 \%$ & $85.06 \%$ \\
Tennessee & $90.17 \%$ & $93.62 \%$ & $82.50 \%$ \\
Virginia & $95.32 \%$ & $99.75 \%$ & $99.74 \%$ \\
West Virginia & $100 \%$ & $72.48 \%$ & $74.79 \%$ \\
Average & $92.92 \%$ & $91.47 \%$ & $86.64 \%$ \\
\hline
\end{tabular}

TABLE 9

PO'TENTIAL IMPROVEMENTS IN TOTAL RECEIPTS (ALTERNATIVE MODEL)

\begin{tabular}{lrrr}
\hline State & \multicolumn{3}{c}{ Year } \\
\cline { 2 - 4 } & $\mathbf{1 9 9 9}$ & $\mathbf{2 0 0 0}$ & $\mathbf{2 0 0 1}$ \\
\hline Arkansas & $16.27 \%$ & $0 \%$ & $34.83 \%$ \\
Idaho & $3.89 \%$ & $15.11 \%$ & $\mathbf{1 6 . 9 5 \%}$ \\
Indiana & $0 \%$ & $5.71 \%$ & $0 \%$ \\
Illinois & $0.74 \%$ & $0 \%$ & $8.61 \%$ \\
Kentucky & $23.50 \%$ & $13.00 \%$ & $\mathbf{1 8 . 1 9 \%}$ \\
Missouri & $12.32 \%$ & $0.79 \%$ & $34.00 \%$ \\
Ohio & $0 \%$ & $3.74 \%$ & $0 \%$ \\
South Carolina & $17.56 \%$ & $33.89 \%$ & $17.57 \%$ \\
Tennessee & $10.90 \%$ & $6.81 \%$ & $21.21 \%$ \\
Virginia & $4.91 \%$ & $0.26 \%$ & $0.26 \%$ \\
West Virginia & $0 \%$ & $37.98 \%$ & $33.71 \%$ \\
Average & $8.19 \%$ & $10.66 \%$ & $16.85 \%$ \\
\hline
\end{tabular}


and the trucking industry with additional tax hikes. Consequently, poor road infrastructure can create downward spirals of tax hikes, increased trucking business failures, and the subsequent decrease of tax revenue bases. In other words, state government's road/highway budget and planning policy has long-term consequences for the economic viability of the trucking industry and the political survival of the state government. The best way to minimize the conflict of interest among various stakeholders such as state governments, the trucking industry, and general public is to identify the best practices of managing highway finances and utilizing given highway resources.

In this article, a data envelopment analysis designed to analyze the comparative efficiency of state highway finances, identify potential sources of inefficiency, and provide useful information (hindsight) for the continuous improvement of efficiency was proposed. The DEA analysis revealed four best-practice (benchmark) states: Virginia, Indiana, Illinois and Ohio. Of those four states, three are mid-western states. On the other hand, Kentucky, Tennessee and Idaho were identified as underachievers. Among these three, two are southern states with high trucking business failure rates. By examining these states, one of the culprits for poor performance in managing highway funds turned out to be the relatively high price tag for highway construction or maintenance. For instance, Kentucky has the highest composite price index for highway construction among 11 peer states for the years 1992 through 2001. From 1999 to 2001, Kentucky's average composite price index for highway construction was $38 \%$ above the U.S national average. Thus, Kentucky state government needs to avoid any cost overruns associated with construction. One viable option that Kentucky can exercise is to increase the competition for construction bidding process.

Another viable option is to enhance the efficiency of Kentucky's highway fund management. To elaborate, Kentucky should revise its motor vehicle tax provisions because it performed worst in terms of utilizing motor vehicle and carrier taxes. Indeed, Kentucky generated more than twice as much motor vehicle and carrier tax revenues as Indiana, despite the fact that the former had 55\% less registered vehicles than Indiana in 2002. These statistics suggest that Kentucky levied much higher motor vehicle and carrier taxes on its residents and trucking firms than Indiana. Such taxes should be adjusted to the level of other peer states to warrant fair taxation. In other words, tax reforms asking for reduction in motor vehicle and carrier taxes may be needed in the future.

Finally, the five underachiever states (Kentucky, West Virginia, Arkansas, Tennessee, and Idaho) are relatively low income and less populous, whereas the four best performers (Virginia, Ohio, Illinois, Indiana) are higher income and more populous states. 'This is ironic, because poor income states are supposed to utilize their limited financial resources better than their richer counterparts. 'I'his can be partially explained by the fact that richer income and more populous states may have a greater chance to take advantage of their economies of scale (e.g., more lanes per mile) for highway investment, and, therefore, better utilize their resources than poor income and less populous states. Also, all five underachieving states tend to have a higher ratio of rural to urban lanemiles of highways and may experience greater difficulty in building remotely located rural highways on the hills, mountains, and rugged terrains. However, such a finding cannot be generalized because South Carolina performed relatively well despite being a poor income and less populous state. Based on these findings and observations, we suggest the following guidelines for continuous improvement of highway finances are suggested:

- Reassess the transportation needs of a state and develop the performance metric (e.g., traffic volume/capacity ratio) of highways to determine their importance for the long-term economic development of a state; 
- Identify traffic corridors and distribution hubs of statewide significance and develop cost-effective investment strategies for those prioritized highways linking traffic corridors and distribution hubs;

- Reexamine the highway construction bidding process for any questionable contracts and compare the composite price index of highway construction bids to that of peer states on a periodic basis;

- Investigate the potential correlation between road thickness (durability) and marginal maintenance cost and then make an optimal tradeoff between highway durability and maintenance cost;

- Eliminate any double taxation by not charging the same highway user both a toll and a fuel tax;

- Create alternative sources of funding rather than relying on traditional tax revenues. These sources may include: investor equity, donated rights-of-way, private development fees, concession rights leasing, fiber optic cable rights leasing and cost sharing with organizations which benefited from a highway improvement.

To conclude, this article differentiates between succeeding and struggling groups of state governments on the basis of DEA efficiency scores. The DEA efficiency score gives state governments a warning signal that the lower the DEA score is, the greater the likelihood a state government has for downward budget spirals. Thus, DEA is very useful for identifying the least efficient state governments which require the closest attention. However, the proposed DEA model can be extended to include multiple outputs (including non-financial measures) and a greater number of state governments in homogeneous socio-economic settings. Also, future DEA studies may explore the decreasing returns to scale for transforming inputs to outputs as opposed to constant returns to scale that this current study assumed. Furthermore, it would be intriguing to examine the correlation between state highway financial efficiency and state tax increases and the subsequent impact on the trucking industry using the exploratory studies. Along the same line, a future area of research could examine how higher fuel prices and the gasoline tax relief would impact future road construction finances.

\section{ACKNOWLEDGEMENT}

The authors would like to thank Usher Transport Inc. for partly funding this research.

\section{REFERENCES}

Ali, Agha I., Lerme, Catherine S., and Nakosteen, Robert A. (1992), "Assessment of Intergovernmental Revenue Transfers," Socio-Economic Planning Sciences, 27(2): 109-118.

American Trucking Associations Economics and Statistics Group (2001), American Trucking Trends 2002: Findings and Comments Series, Alexandria, VA: Transport Topics Press.
American Trucking Associations Economics and Statistics Group (2004), Standard Trucking and Transportation Statistics, Vol. 10, Issue 3, Alexandria, VA: Transport Topics Press.

Associated Press (2003), "Kentucky Road Projects Face Delay due to Budget Woes," Transport Topics, June: 15. 
Boussofiane, A., Dyson, R.G., and Thanassoulis, E. (1991), "Applied Data Envelopment Analysis," European Journal of Operational Research 52: 1-15.

Chandra, Amitabh and Thompson, Erin (2000), "Does Public Infrastructure Affect Economic Activity? Evidence form the Rural Interstate Highway System," Regional Science and Urban Economics, 30(4): 457-490.

Charnes, A., Cooper, W.W., and Rhodes, E. (1978), "Measuring the Efficiency of Decision Making Units," European Journal of Operational Research 2: 429-444.

Dun and Bradstreet Information Services (1999), Industry Norms and Key Business Ratios, 1998-1999, Murray Hill, NJ: Dunn and Bradstreet, Inc.

Energy Information Agency (2006), "Weekly Retail On-Highway Diesel Prices," retrieved from the U.S. Department of Energy website, http://tonto.eia.doe.gov/oog/info/wohdp / diesel.asp.

Frontier Analyst (1998), Efficiency Analysis Software User's Guide, Professional Edition, Glasgow, Scotland: Banxia Software Ltd.

Furey, T.R. (1987), "Benchmarking: the Key to Developing Competitive Advantages in Mature Markets," Planning Review 15(5): 30 32.

Kentuckians for Better Transportation (2003), "Committee Exploring Bonding to Prevent Project Delays," Transportation Update, August $7^{\text {th }}$. Louisville, KY.

Kleinsorge, Ilene K. and Karney, Dennis F. (1992), "Management of Nursing Homes using Data Envelopment Analysis," SocioEconomic Planning Sciences 26(1): 57-71.
Lambert, Thomas and Min, Hokey (2000), "The Impact of State Taxes on the Development and Growth of Trucking Industry," Journal of Transportation Management, 12(2): 33-46.

Larson, Thomas D. (1991), Highway Statistics 1990 , Federal Highway Administration in the U.S. Department of Transportation, Washington, DC: U.S. Government Printing Office.

Loftus, Tom (2001), "Grand Jury Hears Road Contractors," The Courier-Journal, September 21:B1.

Loftus, Tom (2003), "As Fund Iwindles, Kentucky to Halt or Delay Road Projects," The Courier-Journal, June 16:A1.

Min, Hokey and Joo, Seong Jong (2003), "Benchmarking the Operational Efficiency of Major Trucking Firms using Data Envelopment Analysis," Journal of Transportation Management, 14(2): 22-34.

Min, Hokey and Galle, William, P. (1996), "Competitive Benchmarking of Fastfood Restaurants using the Analytic Hierarchy Process and Competitive Gap Analysis," Operations Management Review 11(2/3): 5772.

Murphy, David J., Pearson, John, N., and Siferd, Sue P. (1996), "Evaluating Performance of the Purchasing Department using Data Envelopment Analysis," Journal of Business Logistics 17(2): 77-91.

Nozick, Linda K., Borderas, Hector, and Meyburg, Arnim, H. (1998), "Evaluating of" Travel Demand Measures and Programs: A Data Envelopment Analysis Approach," Transportation Research A 32(5): 331-343. 
Office of Highway Policy Information (2002), Highway Statistics 2001, Federal Highway Administration, U.S. Department of Transportation, Washington, DC: U.S. Government Printing Office.

Poli, Patricia M. and Scheraga, Carl, A. (2000), "The Relationship between the Functional Orientation of Senior Managers and Service Quality in LTL. Motor Carriers," Journal of Transportation Management 12(2): 17-31.

Seiford, Lawrence M. (1990), "A Bibliography of Data Envelopment Analysis (1978-1990)," Unpublished Working Paper, Department of Industrial Engineering and Operations Research, University of Massachusetts, Amherst.

Shafer, Scott M, and Byrd, Terry, A. (2000), "A Framework for Measuring the Efficiency of Organizational Investments in Information Technology using Data Envelopment Analysis," Omega 28: 125-141.

Sherman, H. David and Ladino, George (1995), "Managing Bank Productivity using Data Envelopment Analysis," Interfaces 25(2): 6073.

Small, Kenneth A., Winston, Clifford, and Evans, Carol A. (1989), Road Work: A New Highway Pricing and Investment Policy, Washington, DC: The Brookings Institution.

SPSS Base 13.0 User's Guide (2004), Chicago, IL: SPSS Inc.
Stevens, James D. (1998), "Cost Estimating and Forecasting for Highway Work in Kentucky," Kentucky Transportation Center Report 98 . 18, Lexington, KY: University of Kentucky.

Talluri, S., Hug, F., and Pinney, W.E. (1997), "Application of Data Envelopment Analysis for Cell Performance Evaluation and Process Improvement in Cellular Manufacturing," International Journal of Production Research 35(8): 2157-2170.

Timmons, Carol B. (2003), "Low Rate of Tax Return from State Hurts Louisville," Business First, December 5: 54.

Thanassoulis, Emmanuel (1999), "Data Envelopment Analysis and Its Use in Banking," Interfaces 29(3): 1-13.

Tongzon, Jose (2001), "Efficiency Measurement of Selected Australian and Other International Ports using Data Envelopment Analysis," Transportation Research A 35: 113-128.

USA Today (2003), "California Low in Spending per Tax Dollars," USA Today, October 16: 2A.

USA Today (2004), "Massive Highway Spending Bill Lacks Financial Road Map," USA Today, February 18: 10A.

Valdmanis, Vivian (1992), "Sensitivity Analysis for DEA Models: An Empirical Example using Public vs. NFP Hospitals," Journal of Public Economics 48: 185-205. 


\section{AUTHOR BIOGRAPHY}

Hokey Min holds the James R. Good chair in Global Supply Chain Strategy in the Department of Management at Bowling Green State University. Dr. Min was professor of supply chain management, distinguished university scholar and founding director of the UPS Center for World-wide Supply Chain Management and the Center for Supply Chain Workforce Development at the University of Louisville. He earned his Ph.D. degree in management sciences and logistics from the Ohio State University. Dr. Min's research interests include global logistics strategy, e-synchronized supply chain, benchmarking, and supply chain modeling. He has published more than 100 articles in various refereed journals including European Journal of Operational Research, Journal of Business Logistics, Journal of the Operational Research Society, Transportation Journal, Journal of Transportation Management, and Transportation Research.

\section{AUTHOR BIOGRAPHY}

Thomas Lambert is currently Visiting lecturer in the Department of Fconomics at Indiana University-Southeast. Prior to the current appointment, Dr. Lambert taught economics, urban and public affairs, and management at both the University of Louisville and Spalding University. He also previously held the position of research manager at the UPS Center for World-wide Supply Chain Management. He received his Ph.D. degree in urban economics from the University of Louisville. 